Acta Theriologica 44 (4): 413-420, 1999.

PL ISSN 0001-7051

\title{
Fox, raccoon dog and badger densities in North Eastern Poland
}

\author{
Jacek GOSZCZYŃSKI
}

\begin{abstract}
Goszczyński J. 1999. Fox, raccoon dog and badger densities in North Eastern Poland. Acta Theriologica 44: 413-420.

The densities of three sympatric carnivore species (fox, raccoon dog and badger) were estimated in Suwałki Landscape Park (North Eastern Poland). The number of predator den was estimated by a double survey of the area; additionally, snow tracking was carried out. Mean spring density (1995-1996) of foxes was estimated on 0.27 individuals per square $\mathrm{km}$ of the whole Park territory whereas those of badgers and raccoon dogs were 0.36 and 0.37 , respectively. These values are much higher than estimations by the Park Authorities. In comparison with other regions of Poland the densities of both raccoon dogs and badgers were among the highest recorded. Mean number of cubs per family den was 2.3 in badgers, 6.0 in foxes and 5.7 in raccoon dogs.

Department of Game Management, Agricultural University of Warsaw, Rakowiecka 26/30, 02-528 Warsaw, Poland and Museum and Institute of Zoology PAS, Wilcza 64, 09-697 Warsaw, Poland

Key words: Vulpes vulpes, Nyctereutes procyonoides, Meles meles, carnivore densities, cub number
\end{abstract}

\section{Introduction}

Among three medium-size carnivores present in Poland, fox Vulpes vulpes (Linnaues, 1758) has been the species most frequently investigated (review in Goszczyński 1995), whereas badger Meles meles (Linnaeus, 1758) and raccoon dog Nyctereutes procyonoides (Gray, 1834) have only sporadically been objects of ecological studies (Włodek and Krzywiński 1986, Sumiński 1989, Goszczyński and Skoczyńska 1996). Also the numerical and ecological relationships between these species have been rarely documented in the literature (Jędrzejewski and Jędrzejewska 1993, Jędrzejewski et al. 1989, Kobylińska 1996).

In some parts of the country the densities of raccoon dog are higher than those of native (fox and badger) predators (Krzywiński and Włodek 1984) probably due to the great reproductive rate and omnivorous diet of this canid (Kauhala et al. 1993, Helle and Kauhala 1995).

In North-East Poland where raccoon dogs have been present for at least forty years (Nowak and Pielowski 1964) the interactions between them and badgers and foxes should be well established. Therefore, this region can be used as a reference area for other parts of the country, which were colonised by raccoon dogs during 
next few years. Suwałki Landscape Park (SLP) also seems to be a good study area for other reasons: its geographical location and mosaics of different habitats generate high densities of all predator species. Moreover, a moderate hunting pressure and absence of rabies, both of which strongly influence carnivore densities elsewhere, provide favourable conditions.

The aim of the study is to estimate the shelter capacity for these three medium-size predators, to evaluate their densities and their reproductive rates (number of cubs per family).

\section{Study area}

The study area located in north-eastern Poland $\left(22^{\circ} 52^{\prime} \mathrm{N}, 54^{\circ} 17^{\prime} \mathrm{E}\right)$ is very diverse in both habitat and geomorphological structure.

The landscape of the Park was formed during the Quaternary period and is characterised by a very complicated relief. In the Park area strong differences in altitudes occur, from 130 to $275 \mathrm{~m}$. The sharp elevation gradients and steep slopes of hills resemble a mountainous landscape and is rather unusual in lowland. The soils were formed from deposits of continental glaciers. Podzolic soils predoninate, and brown and marshy soils are less frequent.

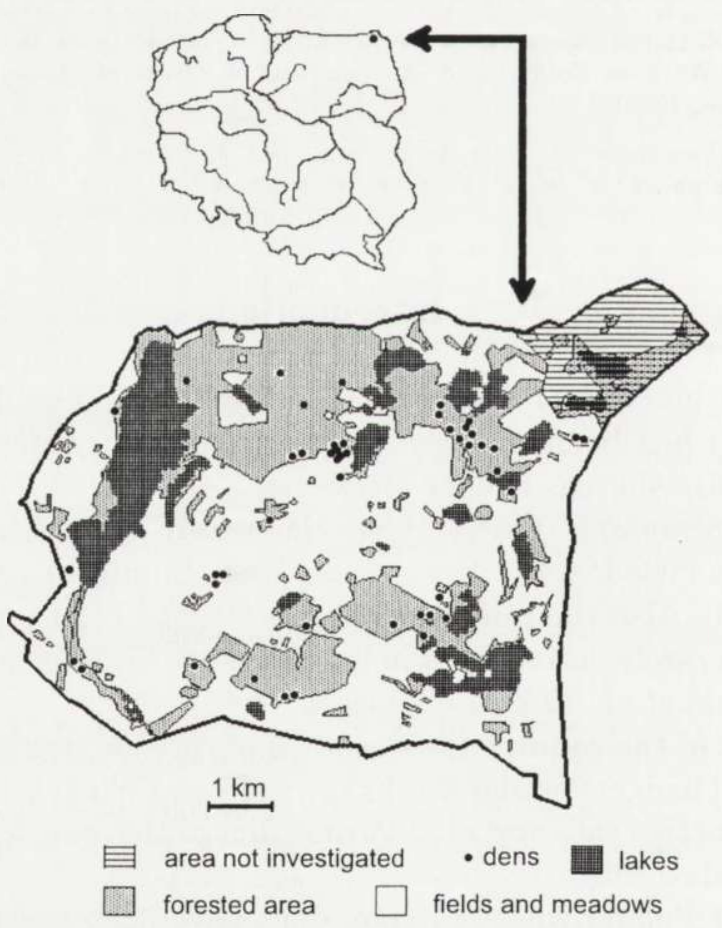

Fig. 1. Study area and distribution of predatory dens. 
The climate is more severe than in other regions of Poland. The influence of a continental climate is well seen with late springs, hot summers and long and severe winters. The snow cover lasts for 100-160 days. The mean temperature in January (the coldest month) varies between $-2^{\circ} \mathrm{C}$ to $-7^{\circ} \mathrm{C}$.

The size of the Park territory is $63 \mathrm{sq} \mathrm{km}$. About $60 \%$ of its surface is occupied by agrocenoses, among them meadows and pasture form a large part. The lakes and bogs take approximately $10 \%$ of the total area, $4 \%$ - wastelands and $2 \%$ other habitat types. The forested and wooded area occupies $24 \%$ of the Park territory. Mixed forest, composed of hazel and spruce with rich undergrowth, predominate. The mixed coniferous forest with pine and spruce ranks second, and the dry coniferous forest third. For more information see Ronkowski (1989).

Both soil type and relief of the area can affect den digging activity of predators, and the mosaic of habitats may facilitate niche separation among the species studied.

\section{Material and methods}

\section{Estimation of total number of dens}

The survey of dens, their density and distribution was carried out in an area previously unknown to observers. Den searching was conducted in very difficult conditions: on steep slopes, in very dense forests with thick undergrowth and abundant deadwood. For these reasons it must be assumed that not all dens present in the study area could be found during the searching sessions.

In order to estimate the total number of predator dens in the area of Suwalski Park the Magnusson et al. (1978) method was applied. Two independent counts of burrows, first performed by the group of observers and second - by a single observer were made in the Park territory. Calculating the den number, the following formula was used:

$$
\mathrm{N}=\frac{(\mathrm{S} 1+\mathrm{B}+1)(\mathrm{S} 2+\mathrm{B}+1)}{(\mathrm{B}+1)}-1
$$

where: S1 - number of burrows found by the first group of observers only, S2 - number of burrows found ay the second observer but not by the first, B - number of dens recorded by both, and $\mathrm{N}$ - total number of burrows in the study area.

The first survey of dens was carried out in August 1995. It encompassed the areas along $900 \mathrm{~km}$ route and lasted about $300 \mathrm{hrs}$. Den searching was performed by a group of students on an area of 59 square kilometres within the whole Park, except for its north-eastern part (Fig. 1). During the survey, mostly wooded areas and forests were examined. More attention was paid to areas of diversified relief (steep slope of hills, and walls of ravines), because such places are frequently chosen by predators for den lotation. Two neighbouring dens were treated as independent shelters, if the distance between their rearest entrances was greater than 20 meters.

Alldens or den complexes were mapped (on a 1: 25,000 cartographic map), and marked directly in the fied with ribbons tied to the nearest tree.

Th: second survey in the same area was performed by a single observer from spring 1995 to July 1996. He had no contact with members of the first group and searched the area randomly. Additionally he courted number of cubs present in the dens (see below).

\section{Nimber of dens occupied by particular predator species and cub estimation}

In the case of each den an attempt was made to establish which species was using it. The identifcation was made mainly on the basis of animal tracks present at the entrances and in close proximty to the burrows. Other signs of animal presence also taken into account were the following: (1) carion and remnants of prey, (2) faeces of cubs, (3) typical odour, (4) appearance of latrines.

Both badgers and raccoon dogs, deposit their faeces in special places called latrines. Badger latrines are locted in small holes dug in the ground; faeces deposited into it are amorphous. In contrast, raccoor dogs deposit their cylindrical scats in one place at ground level, forming a cone after some time. Cccasionally, however raccoon dog latrines are located at the entrance of dens in holes similar to 
badgers latrines. In such case predator species may be distinguished on the basis of faeces' shape and (or) by tracks.

In August, at the time of the first survey, only badgers and raccoon dogs were still present in the dens, using latrines and leaving fresh tracks. In the cases of foxes, which by August had left already family dens, the identification of dens once used by them was more difficult. It was made on the basis of remains of prey, carrion and cub scats still present around the dens. In the next year, the surveys were made repeatedly, from the beginning of breeding season and with greater intensity, so it was possible to distinguish dens occupied by different species more accurately. In case of badger setts, family setts and dens used by single individuals could also be distinguished, basing on number of tracks and on observation.

In the study area, fox cubs appeared on the surface in May. Cubs of badgers and raccoon dogs left their dens much later, at the end of May and in June. Counts of cubs and adults animals were performed at the occupied burrows during May and June. Cubs appearing on the surface during the observations was counted. The total number of cubs was established as a maximum number seen at the burrow during observations made repeatedly.

During two successive breeding seasons, 51 observations, of total duration of about $86 \mathrm{hrs,} \mathrm{at}$ occupied dens were made. They allowed for the evaluation of litters of 6 badgers, 9 foxes and 12 raccoon dogs. Some of the cub counts (7) for foxes and raccoon dogs were performed in the vicinity of Suwalki Landscape Park in Szurpily Forestry District. Due to the fact of the close proximity of this area to boundaries of the Park (mean distance between dens and boundaries aprox. $2.3 \mathrm{~km}$ ) these data were added to the material originating from the SLP area.

Foxes were also surveyed by snow tracking during two winters 1994/95 and 1995/96 in forest and in open areas, on transects of total length $30.8 \mathrm{~km}$. During the 2nd and 3rd day after a new snow fall, the transects were walked and the tracks of foxes crossing the track were noted. The number of recorded tracks were converted into the number of tracks $\mathrm{km}^{-1} \mathrm{~d}^{-1}$. Then the mean index (n tracks $\mathrm{km}^{-1} \mathrm{~d}^{-1}$ ) for the winter was calculated and used for estimating the density of foxes, according the method by Priklonski (1965). The daily movement distance typical for a fox under severe winter conditions (9.1 km - Goszczyński 1986) was used for density estimations in winter. Densities of foxes established by snow tracking were then compared with those estimated on the basis of den counts in spring seasons.

\section{Results}

\section{The total number of burrows}

In summer 1995, 26 dens were found. The second observer found 37 dens 14 of which were the dens discovered in summer 1995. According to formula 1 a total number of burrows in Park was estimated at 67 with 8.9 (SE).

The dens examined on 1995 formed aprox. 39\% of all dens occurring the whole Park territory, whereas in 1996 percentage of controlled burrows was higher (67\%).

\section{Number of burrows occupied by each predator species and cub number}

Among 26 burrows found in summer 1995 in the study area, 6 were setts occupied by badgers, 4 were classified as fox family dens, and 4 as raccoon dog family dens. Since burrows found in 1995 formed 39\% of the total dens present in the Park, it could be expected that in fact 15 badgers setts, 10 fox dens and raccoon dog burrows were present in the study area.

In the spring 1996, 45 dens were examined. Among them 10 were setts of badger ( 4 occupied by badger families and 6 by single animals), 4 were identified as family 
Table 1. Number of dens occupied by particular predatory species in the Suwałki Landscape Park.

\begin{tabular}{|c|c|c|c|c|}
\hline \multirow{3}{*}{ Species } & \multicolumn{2}{|c|}{1995} & \multicolumn{2}{|c|}{1996} \\
\hline & \multicolumn{2}{|c|}{ Number of dens } & \multicolumn{2}{|c|}{ Number of dens } \\
\hline & examined & in Park & examined & in Park \\
\hline Total number of dens & 26 & 67 & 45 & 67 \\
\hline \multicolumn{5}{|l|}{ Badger } \\
\hline all setts & 6 & 15 & 10 & 15 \\
\hline family setts & & & 4 & 6 \\
\hline $\begin{array}{l}\text { setts occupied by } \\
\text { single individuals }\end{array}$ & & & 6 & 9 \\
\hline Fox family dens & 4 & 10 & 4 & 6 \\
\hline Raccoon dog dens & 4 & 10 & 8 & 12 \\
\hline
\end{tabular}

Table 2. Mean number of cubs per family dens.

\begin{tabular}{|c|c|c|c|c|c|c|}
\hline \multirow{3}{*}{ Species } & \multicolumn{2}{|c|}{1995} & \multicolumn{2}{|c|}{1996} & \multicolumn{2}{|c|}{ Whole period } \\
\hline & \multicolumn{2}{|c|}{ Number of } & \multicolumn{2}{|c|}{ Number of } & \multicolumn{2}{|c|}{ Number of } \\
\hline & litters & cubs & litters & cubs & litters & cubs (SD) \\
\hline Badger & 2 & 2.5 & 4 & 2.2 & 6 & $2.33(0.52)$ \\
\hline Fox & 3 & 6.0 & 6 & 6.0 & 9 & $6.00(0.71)$ \\
\hline Raccon dog & 3 & 5.7 & 9 & 5.8 & 12 & $5.75(0.75)$ \\
\hline
\end{tabular}

fox den and 8 as family raccoon dog dens. The numbers of dens of each predator species in 1996, recalculated as before for the whole Park territory, was similar to those estimated in 1995, except for foxes (Table 1).

Mean numbers of cubs observed at the dens were estimated at 2.3 for badger, 6.0 for fox, and 5.7 for raccoon dog (Table 2).

\section{Density}

In Poland, raccoon dogs and foxes live in pairs, so it was assumed that in each family den, two adult animals were present. In the case of badgers in the studied area, no more than two adults were ever observed in a sett. Therefore it was assumed that two adult animals are typical for a family sett and one - for a temporary sett.

Average spring density for two years for badgers, foxes and raccoon dogs was: $0.36,0.27$ and 0.37 adult individuals per 1 square kilometre of the whole Park area. After adding to these values the number of cubs, the densities increased to: 0.59 
Table 3. Yearly mean number of occupied dens at the end of spring and density of predators in Suwałki Landscape Park (whole investigated Park area $59 \mathrm{~km}^{2}$ ).

\begin{tabular}{|c|c|c|c|c|c|c|}
\hline \multirow{2}{*}{ Species } & \multirow{2}{*}{$\begin{array}{l}\text { Mean number } \\
\text { of occupied dens }\end{array}$} & \multicolumn{3}{|c|}{ Number of animals } & \multicolumn{2}{|c|}{ Density $/ 1 \mathrm{~km}^{2}$} \\
\hline & & juv & ad & sum & whole Park & forested area \\
\hline \multicolumn{7}{|l|}{ Badger } \\
\hline family setts & 6 & 14 & 12 & 26 & & \\
\hline setts with single animals & 9 & & 9 & & & \\
\hline all sets & 15 & 14 & 21 & 35 & 0.59 & 2.45 \\
\hline Fox & 8 & 48 & 16 & 64 & 1.08 & 4.52 \\
\hline Raccoon dog & 11 & 63 & 22 & 85 & 1.44 & 6.00 \\
\hline
\end{tabular}

ind. $/ \mathrm{km}^{2}$ (badger), 1.08 ind. $/ \mathrm{km}^{2}$ (foxes) and 1.44 ind. $/ \mathrm{km}^{2}$ (raccoon dogs). Densities expressed as number of individuals per one sq kilometre of the forested area were about four times higher (Table 3).

In winter tracking, 2.1 fox trails per 1 kilometre of census route were recorded. This index is equivalent to the density of 0.38 indiv. per $1 \mathrm{sq}$ kilometre. According to this estimate the whole number of foxes present in the Park during winter is 22 individuals or 11 fox pairs.

\section{Discussion}

The estimated number of badger setts was probably close to reality because badgers use their dens for a long period and because badger setts are large underground constructions which are easy to find.

The number of burrows for raccoon dogs and foxes (and the calculated densities of these predators) may be slightly underestimated. Raccoon dogs may sometimes choose unusual shelters for breeding eg holes in trees, windfalls and piles of wood debries (Włodek and Krzywiński 1986). Foxes, in certain regions, tend to locate their dens in open areas (fields) (Pielowski 1976). Some of dens found in the Park were located in small woodlots and in treeless places. There is a possibility that some dens situated outside forest areas were omitted during burrow searching. Therefore densities for both foxes and raccoon dogs could be underestimated.

However the fox density stated in the Park is comparable to that reported for many other regions of Poland (Pielowski 1976, Fedyk et al. 1984, Jędrzejewski and Jędrzejewska 1993, and Jamrozy 1994), but lower than that recorded in the central part of the country (Goszczyński 1989).

The winter density $\left(0.38\right.$ ind.$\left./ \mathrm{km}^{2}\right)$ is approximately $38 \%$ higher than the spring density $\left(0.27\right.$ ind. $\left./ \mathrm{km}^{2}\right)$. Since some foxes could not find partners in spring, and other died between winter and spring censuses, such a decrease in numbers in spring seems realistic. 
On the other hand, densities of the raccoon dog and the badger are among the highest recorded in Poland (Krzywiński and Włodek 1984, Włodek and Krzywiński 1986, Żurowski 1989, Goszczyński and Skoczyńska 1996).

In the Suwałki Park, an inventory of predators (foxes and raccoon dogs) inhabiting the Park territory is performed each year by Park rangers. According to their data for a period 1992-1996, the mean number of predators at the beginning of breeding season (31 March) was 6.5 for foxes and 10.7 for raccoon dogs. These values are at least two times lower than these reported in the present study. However, in both Park estimates and in the present study higher densities of raccoon dogs than foxes are evident.

High predator densities in Suwałki Landscape Park are probably the result of several favourable factors: (1) abundance of shelters in the Park, (2) diversity of habitats which provide sufficient food for each predator species, (3) moderate level of hunting (mean annual harvest was 10 for foxes in a period of 1990-1996, whereas badgers and raccoon dogs were not hunted in all the Park territory), and (4) no rabies epidemics during last years.

Further study is required to investigate mortality factors, especially in the raccoon dog population.

Acknovledgements: I thank the Suwałki Landscape Park (SLP) Board for facilities provided. I wish to express my sincere gratitude to M. Sc. J. Borejszo - director of SLP for his help during the field studies I am also grateful to the students of Agricultural University of Warsaw, who participated in the ressarch, as well as to M. Sc. Z. Liszewski for their help with dens searching and cub observations. I express my gratitude to Professor J. Gliwicz and to the anonymous reviewers for their valued comments on this paper. The research was partly sponsored by Agricultural University of Warsaw and Museun and Institute of Zoology PAS and partly by grant KBN No 6P205 070407 from the Polish Commitee for Scientific Research.

\section{References}

Fedyk S., Gçbczyńska Z., Pucek M., Raczyński J. and Sikorski M. D. 1984. Winter penetration by manmals of different habitats in the Biebrza Valley. Acta Theriologica 29: 317-336.

Goszczýski J. 1986. Locomotor activity of terrestrial predators and its consequences. Acta Theriologica 31:79-95.

Goszczŕski J. 1989. Population dynamics of the red fox in Central Poland. Acta Theriologica 34 141-154.

Goszczński J. 1995. [The fox]. Oikos, Warszawa: 1-137. [In Polish]

Goszczński J. and Skoczyńska J. 1996. Density estimation, family group size and recruitment in a badyer population near Rogów (Central Poland). Miscel.lània Zoològica 19(2): 27-33.

Helle E and Kauhala K. 1995. Reproduction in the raccoon dog in Finland. Journal of Mammalogy 75: $1033-1046$.

Jamrozy G. 1994. The occurrence, distribution and population of game animals in the Polish Canathian Mountains. Zeszyty Naukowe Akademii Rolniczej im Hugona Kołłąaja w Krakowie 190 1-104. [In Polish with English summary]

Jędrzej:wski W. and Jędrzejewska B. 1993. Predation on rodents in Białowieża primeval forest, Poland. Ecoraphy 16: 47-64.

Jędrzejıwski W., Jędrzejewska B. and Szymura A. 1989. Food niche overlaps in a winter community of preiators in the Białowieża Primeval Forest, Poland. Acta Theriologica 34: 487-496. 
Kauhala K., Kaunisto M. and Helle E. 1993. Diet of the raccoon dog, Nyctereutes procyonoides, in Finland. Zeitschrift für Säugetierkunde 58: 129-136.

Kobylińska J. 1996. The red fox and raccoon dog in wetland of the Biebrza River Valley - food composition and burrows use. Journal of Wildlife Research 1: 186-189.

Krzywiński A. and Włodek K. 1984. [Raccoon dog]. Łowiec Polski 4: 12-13. [In Polish]

Magnusson W. E., Caughley J. G. and Grigg G. C. 1978. A double-survey estimate of population size from incomplete counts. The Journal of Wildlife Management 42: 174-176.

Nowak E. and Pielowski Z. 1964. Die Verbreitung des Marderhundes in Polen in Zusammenhang mit seiner Einbürgerung and Ausbreitung in Europa. Acta Theriologica 9: 81-110.

Pielowski Z. 1976. The role of foxes in the reduction of the European hare population [In: Ecology and management of European hare populations. Z. Pielowski and Z. Pucek, eds]. Państwowe Wydawnictwo Rolnicze i Leśne, Warszawa: 135-148.

Priklonsky S. G. 1965. Coefficients to treat the data of winter transect method of census taking of game animals by their traces. Bjulleten Moskovskogo Obshchestva Ispytatelej Prirody. Otdelenie Biologii, 70: 5-12. [In Russian with English summary]

Ronkowski G. 1989. [Suwalski Landscape Park]. Polskie Towarzystwo Turystyczno Krajoznawcze "Kraj", Warszawa: 1-19. [In Polish]

Sumiński P. 1989. [The badger. Ecological monograph]. Państwowe Wydawnictwo Rolnicze i Leśne, Warszawa: 1-128. [In Polish]

Włodek K. and Krzywiński A. 1986. Zu Biologie und Verhalten des Marderhunds (Nyctereutes procyonoides) in Polen. Zeitschrift für Jagdwissenschaft 32: 203-214.

Żurowski W. 1989 [The raccoon dog]. [In: Hunting. J. Krupka, ed]. Państwowe Wydawnictwo Rolnicze i Leśne, Warszawa: 215-219. [In Polish]

Received 30 July 1998, accepted 22 June 1999. 